\title{
PENGUJIAN PERSYARATAN ANALISIS (UJI HOMOGENITAS DAN UJI NORMALITAS)
}

\author{
Usmadi \\ Prodi Pendidikan Matematika FKIP Universitas Muhammadiyah Sumatera Barat \\ usmadidttumanggung@gmail.com
}

\begin{abstract}
Testing prerequisite analysis is the basic concept for determining which test statistics are needed, whether the test uses parametric or non-parametric statistics. The prerequisite test, namely the homogeneity test and normality test. The homogeneity test was carried out in order to test the variance of each group of research data, while the normality test was to determine whether or not the distribution of the research data was normal. Homogeneity testing can be done using the Harley test statistic, the Cohran test, the Levene test, and the Bartlett test. While the linearity test used the Lilliefors test statistic and the Kolmogorov-Smirnov test.

Keywords: Homogeneity Test, Normality Test, Requirements Analysis.
\end{abstract}

\begin{abstract}
Abstrak
Pengujian prasyarat analisis, merupakan konsep dasar untuk menetapkan statistik uji mana yang diperlukan, apakah uji menggunakan statistik parametrik atau non parametrik. Uji prasyarat, yakni uji homogenitas variansi populasi, uji normalitas untuk sebaran data hasil penelitian. Uji homogenitas menggunakan statistik uji Harley, uji Cohran, Uji Levene, dan uji Bartlett. Sedangkan uji linearitas menggunakan statistik uji Lilliefors, dan uji Kolmogorov-Smirnov.
\end{abstract}

Kata Kunci: Uji Homogenitas, Uji Normalitas, Persyaratan Analisis.

\section{PENDAHULUAN}

Sering permasalahan yang dihadapi oleh peneliti, menyangkut pengambilan keputusan berdasarkan data mengenai suatu sistem ilmu. Untuk tiap kasus harus melibatkan penggunaan data percobaan dan pengambilan keputusan berdasarkan data resmi ( Walpole, 1995: 327). Data tiap percobaan atau kasus, memerlukan suatu dugaan (estimasi). Estimasi dapat dirumuskan dalam bentuk hipotesis statistik.

Prosedur seorang peneliti untuk menyimpulkan yakni menerima atau menolak hipotesis statistik, membutuhkan suatu statistik inferensial. Statistik inferensial berhubungan dengan pendugaan populasi dan pengujian hipotesis statistik dari data atau keadaan atau fenomenayang ada (Supardi,2013). Dengan demikian, statistika inferensial berfungsi untuk meramalkan mengontrol keadaan atau kejadian.

Kebenaran dan ketidakbenaran suatu hipotesis statistik tidak akan pernah diketahui secara pasti, kalau tidak seluruh populasi diamati atau dijadikan sampel penelitian (Total Sampling). Perumusan suatu hipotesis statistik dipengaruhi oleh peluang kesimpulan yang keliru. Bila seorang peneliti ingin mencari dukungan yang kuat terhadap suatu estimasi, sipeneliti akan berusaha menempatkan estimasinya dalam bentuk penolakan estimasi. Misalnya peneliti dalam pendidikan matematika ingin menunjukkan kenyataan yang kuat bahwa model pembelajaran ARCSI dapat meningkatkan hasil belajar matematika peserta didik maka hipotesis yang diuji seharusnya berbentuk " Model pembelajaran ARCSI tidak dapat menaikkan hasil belajar matematika peserta didik". Akibatnya, estimasi diperkuat dengan penolakan. Begitupula sebaliknya, untuk mendukung estimasi bahwa model pembelajaran ARCSI lebih baik dari model pembelajaran lainnya, maka sipeneliti menguji hipotesis bahwa tidak terdapat perbedaan hasil 
belajar peserta didik yang diajar dengan menerapkan model pembelajaran ARCSI dengan model pembelajaran lainnya.

Dalam rangka menguji hipotesis statistik, maka peneliti terlebih dahulu menentukan statistik uji mana yang tepat digunakan, apakah menggunakan uji statistik parametrik atau non parametrik (Supardi, 2013: 129). Dalam penggunaan uji statistik parametrik dan non parametrik, perlu dilaksanakan uji persyaratan analisis. Pengujian dengan uji statistik inferensial parametrik mensyaratkan uji normalitas, uji homogenitas variansi, dan uji linearitas.

Langkah uji hipotesis statistik yang dapat dilakukan oleh seorang peneliti dalam melakukan uji persyaratan analisis, yakni: (1) rumuskan hipotesis $\mathrm{H}_{0}$ dan $\mathrm{H}_{1}$; (2) Tetapkan tingkat signifikansi $\alpha$; (3) Tetapkan daerah kritis atau daerah dimana $\mathrm{H}_{0}$ ditolak atau $\mathrm{H}_{1}$ diterima; (4) Tetapkan statistik uji; (5) Lakukan perhitungan; (6) Ambil kesimpulan (Ergusni, 2015: 53-54).

Berdasarkan pembahasan di atas, melihat begitu pentingnya uji prasyarat analisis ini, maka tulisan ini akan memperkenalkan, sekaligus memberikan pengetahuan terkait dengan uji prasyarat analisis. Uji prasyarat analisis yang dibahas dalam tulisan ini adalah uji homogenitas variansi populasi dan uji normalitas dari data suatu penelitian.

\section{METODOLOGI}

Jenis penelitian ini adalah penelitian kualitatif. Dalam penelitian kualitatif peneliti tidak langsung terjun ke lapangan dalam pencarian sumber data hasil penelitian. Salah satu penelitian yang termasuk ke dalam penelitian kualitatif adalah penelitian kepustakaan (Library Research). Dalam penelitian kepustakaan ini kegiatan yang dilakukan lebih kepada olahan filosofis dan teoritis daripada uji empiris di lapangan. Penelitian ini berbasis analisis buku referensi pembelajaran statistika dan metodologi penelitian di perguruan tunggi. Langkah-langkah yang dilakukan dalam penelitian ini adalah (1) mencari buku atau artikel yang sesuai dengan topik yang akan diteliti, (2) mengutip sumber atau mendokumentasikan sumber-sumber yang digunakan, (3) menganalisis dan membuat laporan hasil penelitian.

\section{HASIL PENELITIAN DAN PEMBAHASAN \\ 1. Uji Homogenitas}

Uji homogenitas digunakan untuk mengetahui apakah beberapa varian populasi adalah sama atau tidak. Uji ini dilakukan sebagai prasyarat dalam analisis independent sample t test dan Anova. Asumsi yang mendasari dalam analisis varian (Anova) adalah bahwa varian dari populasi adalah sama. Uji kesamaan dua varians digunakan untuk menguji apakah sebaran data tersebut homogen atau tidak, yaitu dengan membandingkan kedua variansnya. Jika dua kelompok data atau lebih mempunyai varians yang sama besarnya, maka uji homogenitas tidak perlu dilakukan lagi karena datanya sudah dianggap homogen. Uji homogenitas dapat dilakukan apabila kelompok data tersebut dalam distribusi normal. Uji homogenitas dilakukan untuk menunjukkan bahwa perbedaan yang terjadi pada uji statistik parametrik (misalnya uji t, Anava, Anacova ) benar-benar terjadi akibat adanya perbedaan antar kelompok, bukan sebagai akibat perbedaan dalam kelompok.

Uji homogenitas variansi sangat diperlukan sebelum membandingkan dua kelompok atau lebih, agar perbedaan yang ada bukan disebabkan oleh adanya perbedaan data dasar (ketidakhomogenan kelompok yang dibandingkan). Ada beberapa rumus yang bisa digunakan untuk uji homogenistas variansi di antaranya: uji Harley, uji Cohran, Uji Levene, dan uji Bartlett. 


\section{a. Uji Harley}

Uji Harley merupakan uji homogenitas variansi yang sangat sederhana karena cukup membandingkan variansi terbesar dengan variansi terkecil. Uji homogenitas variansi dengan rumus Harley bisa digunakan jika jumlah sampel antar kelompok sama Misal ada dua populasi normal dengan varians $\sigma_{1}^{2}$ dan $\sigma_{2}^{2}$. Akan diuji mengenai uji dua pihak untuk pasangan hipotesis:

$H_{o}: \sigma_{1}^{2}=\sigma_{2}^{2}$

$H_{1}: \sigma_{1}^{2} \neq \sigma$

Statistik yang digunakan untuk menguji hipotesis $H_{0}$ adalah:

$F=\frac{\text { varians terbesar }}{\text { varians terkecil }}$

Dimana tolak $H_{0}$ jika $F_{H i t u n g} \geq F_{1 / 2 \alpha}\left(v_{1}, v_{2}\right)$

Contoh; Skor hasil uji coba 4 metode dalam suatu penelitian sebagai berikut:

Tabel 1. Skor hasil uji coba 4 metode pembelajaran dalam suatu penelitian

\begin{tabular}{c|ccc|}
\hline Kelompok A & Kelompok B & Kelompok C & Kelompok D \\
\hline 25 & 26 & 21 & 28 \\
30 & 31 & 29 & 28 \\
32 & 38 & 29 & 36 \\
36 & 39 & 31 & 37 \\
40 & 39 & 37 & 39 \\
\hline
\end{tabular}

Pertanyaan: Apakah variansi keempat kelompok tersebut homogen?

Penyelesaian:

1. Rumuskan Hipotesis

$$
\begin{aligned}
& H_{0}: \sigma_{A}^{2}=\sigma_{B}^{2}=\sigma_{C}^{2}=\sigma_{D}^{2} \\
& H_{1}: \text { salah satu } \sigma^{2} \text { tidak sama }
\end{aligned}
$$

2. Tetapkan Tingkat signifikansi $\alpha=0,05$

3. Tetapkan Daerah Kritis

Daerah kritis adalah daerah dimana Hipotesis statitik $\mathrm{H}_{0}$ ditolak atau $\mathrm{H}_{1}$ diterima, yakni:

$F_{\text {Hitung }} \geq F_{1 / 2 \alpha\left(v_{1}, v_{2}\right)}$

4. Tetapkan statistik uji

Statitik uji yang digunakan adalah uji F, yakni :

$F=\frac{\text { varians terbesar }}{\text { varians terkecil }}$

5. Lakukan Perhitungan, yakni:

a. Langkah pertama adalah mencari variansi data setiap kelompok:

Variansi Kelompok A

Untuk menentukan variansi kelompok A digunakan rumus:

$$
\begin{aligned}
s^{2} & =\frac{\sum x^{2}-\frac{\left(\sum x\right)^{2}}{n}}{n-1} \\
& =\frac{5445-5313,8}{4}
\end{aligned}
$$

Jadi $s^{2}=32,8$ 
b. Dengan cara yang sama diperoleh:

Variansi Kelompok $B=34,3$

Variansi Kelompok $C=32,8$

Variansi Kelompok $D=27,8$

c. Setelah variansi setiap kelompok diperoleh maka dibandingkan variansi terbesar dan variansi terkecil, dan digunakan rumus

$$
\begin{aligned}
& \begin{aligned}
F & =\frac{\text { varians terbesar }}{\text { varians terkecil }} \\
& =\frac{34,3}{27,8}
\end{aligned} \\
& \text { Jadi } \mathrm{F}_{\text {hitung }}=1,233
\end{aligned}
$$

d. Bandingkan $\mathrm{F}_{\text {Tabel }}$ dengan $\mathrm{F}_{\text {Hitung. Diperoleh }} F_{\text {tabel }}=F_{0,05(n-1, k)}=F_{0,05(4,4)}=6,39$ sedangkan $F_{\text {hitung }}=1,233$. Sehingga diperoleh:

$F_{\text {hitung }}<F_{\text {tabel }}$ atau $1,233<6,39$

e.Ambil simpulan

Berdasarkan hasil perhitungan diperoleh $F_{\text {hitung }}<F_{0,05(4,4)}$, dapat disimpulkan bahwa terima $H_{o}$ artinya variansi keempat kelompok data homogen atau data berasal dari populasi yang memiliki variansi yang sama.

\section{b. Uji Cochran}

Cochran mempertimbangkan seluruh variansi yang akan diuji homogenitasnya, sehingga Uji Cochran lebih sensitif dibandingkan dengan uji Harley. Jika salah satu variansi kelompok jauh lebih besar dibandingkan dengan variansi kelompok yang lain, maka uji Cochran tampak lebih baik daripada uji Harley. Kesamaan uji Cochran dan Uji Harley adalah menuntut adanya kesamaan $\mathrm{n}$ dari setiap kelompok yang akan dicari homogenitasnya.

Rumus dari Uji Cochran adalah:

$$
C_{\text {hitung }}=\frac{\text { variansi terbesar }}{\text { jumlah seluruh variansi }}
$$

Kriteria pengujian adalah membandingkan hasil rumus Cochran dengan tabel Cochran Terima $H_{o}$ jika $C_{\text {hitung }} \leq C_{\text {tabel }}$ dan tolak $H_{o}$ jika $C_{\text {hitung }}>C_{\text {tabel }}$

Jika soal di atas di hitung dengan Uji Cochran akan menghasilkan perhitungan sebagai berikut:

Penyelesaian:

1. Rumuskan Hipotesis

$$
\begin{aligned}
& H_{0}: \sigma_{A}^{2}=\sigma_{B}^{2}=\sigma_{C}^{2}=\sigma_{D}^{2} \\
& H_{1}: \text { salah satu } \sigma^{2} \text { tidak sama }
\end{aligned}
$$

2. Tetapkan Tingkat signifikansi $\alpha=0,05$

3. Tetapkan Daerah Kritis

Daerah kritis adalah daerah dimana Hipotesis statitik $\mathrm{H}_{0}$ ditolak atau $\mathrm{H}_{1}$ diterima, yakni:

$$
C_{\text {hitung }}>C_{\text {tabel }} \text { atau } C_{\text {Tabel }}=C_{0,05(4,4)}=0,6841
$$


4. Tetapkan statistik uji

Statitik uji yang digunakan adalah uji C, yakni :

$$
C_{\text {hitung }}=\frac{\text { variansi terbesar }}{\text { jumlah seluruh variansi }}
$$

5. Lakukan Perhitungan, yakni:

Jumlah seluruh variansi: $32,8+34,3+32,8+27,3=127,2$

$$
\begin{aligned}
& \begin{aligned}
C_{\text {hitung }} & =\frac{\text { varians terbesar }}{\text { jumlah seluruh variansi }} \\
& =\frac{34,3}{127,2} \\
& =0,269
\end{aligned} \\
& \text { Sementara } C_{\text {tabel }}=C_{0,05(4,4)}=0,6841 \\
& \text { Sehingga diperoleh } C_{\text {hitung }}<C_{0,05(4,4)}
\end{aligned}
$$

6. Kesimpulan: karena $C_{\text {hitung }}<C_{0,05(4,4)}$ atau $0,269<0,6841$, maka Terima $H_{o}$ yang berarti keempat kelompok data homogen. Artinya data berasal dari populasi yang variansnya sama

\section{c. Uji Levene}

Uji levene ( levene 1960 ) digunakan untuk menguji kesamaan varians dari beberapa populasi. Uji levene merupakan uji alternatif dari uji Bartlett. Jika ada bukti yang kuat bahwa data berdistribusi normal atau mendekati normal, maka uji Bartlett lebih baik digunakan. Uji Levene menggunakan analisis varian satu arah. Data ditranformasikan dengan jalan mencari selisih masing-masing skor dengan rata-rata kelompoknya. Hipotesis yang digunakan pada uji ini adalah:

$H_{o} \vdots \sigma_{1}^{2}=\sigma_{2}^{2}=\cdots=\sigma_{k}^{2}$

$H_{1} \vdots \sigma_{i} \neq \sigma_{j}$ untuk sedikitnya satu pasang $(\mathrm{i}, \mathrm{j})$

Formula Lavene adalah:

$$
W=\frac{(n-k)}{(k-1)} \frac{\sum_{i=1}^{k} n_{i}\left(\bar{Z}_{i}-\bar{Z} . .\right)^{2}}{\sum_{i=1}^{k} \sum_{j=1}^{n_{i}}\left(Z_{i j}-\bar{Z}_{i .}\right)^{2}}
$$

Dimana:

$\mathrm{n}$ adalah jumlah perlakuan

$\mathrm{k}$ adalah banyak kelompok

$Z_{i j}=\left|Y_{i j}-\bar{Y}_{i .}\right|$

$\bar{Y}_{i .}$ adalah rata - rata dari kelompok ke $-i$

$\bar{Z}_{i .}$ adalah rata - rata kelompok dari $Z_{i}$

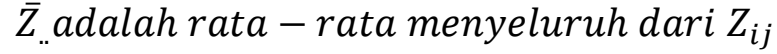

Daerah kritis:

Tolak $H_{o}$ jika $W>F_{(\alpha ; k-1, n-k)}$

Contoh penggunaan, Jika digunakan soal pada uji Harley di atas maka hasilnya sebagai berikut:

Penyelesaian:

1. Rumuskan Hipotesis Statistik, yakni: 
$H_{o} \vdots \sigma_{1}^{2}=\sigma_{2}^{2}=\cdots=\sigma_{k}^{2}$

$H_{1} \vdots \sigma_{i} \neq \sigma_{j}$ untuk sedikitnya satu pasang $(\mathrm{i}, \mathrm{j})$

2. Tetapkan tingkat signifikansi $\alpha=0,05$.

3. Tetapkan daerah kritis, yakni daerah dimana $\mathrm{H}_{0}$ ditolak jika $W>F_{(\alpha ; k-1, n-k)}$ $W>F_{(0,05 ; 3,16)}=3,24$

4. Tetapkan Statistik uji, yakni:

$$
W=\frac{(n-k)}{(k-1)} \frac{\sum_{i=1}^{k} n_{i}\left(\bar{Z}_{i}-\bar{Z} . .\right)^{2}}{\sum_{i=1}^{k} \sum_{j=1}^{n_{i}}\left(Z_{i j}-\bar{Z}_{i .}\right)^{2}}
$$

5. Lakukan Perhitungan, diperoleh:

Tabel 2. Uji Homogenitas dengan menggunakan statistik Uji Harley

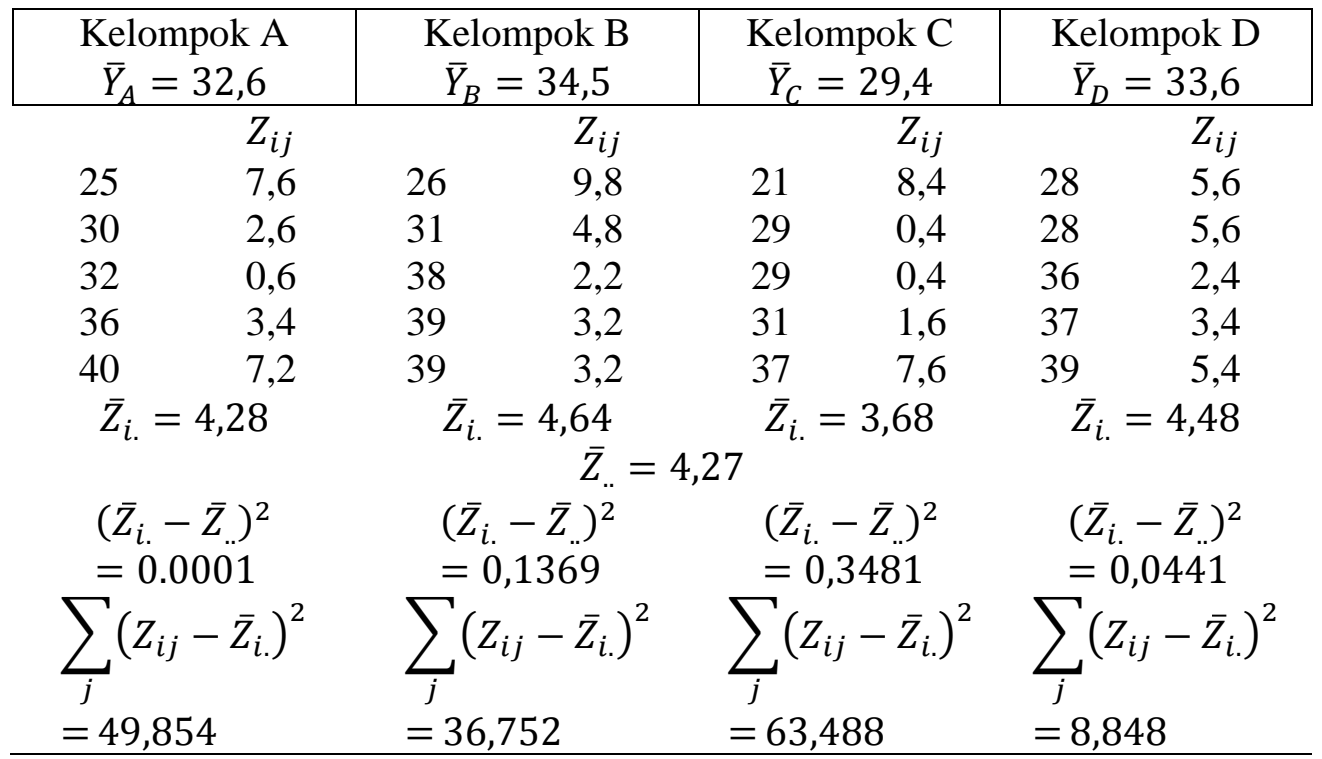

Sehingga :

$$
\begin{gathered}
\sum_{i} n_{i}\left(\bar{Z}_{i .}-\bar{Z}_{. .}\right)^{2}=5.0,0001+5.0,1369+5.0,3481+5.0,0441 \\
=2,646 \\
\begin{aligned}
\sum_{i} \sum_{j}\left(Z_{i j}-\bar{Z}_{i .}\right)^{2}=49,854+36,752 & +63,488+8,848 \\
& =158,942 \\
W=\frac{(n-k)}{(k-1)} \frac{\sum_{i=1}^{k} n_{i}\left(\bar{Z}_{i}-\bar{Z} . .\right)^{2}}{\sum_{i=1}^{k} \sum_{j=1}^{n_{i}}\left(Z_{i j}-\bar{Z}_{i .}\right)^{2}}= & \frac{(20-4)}{(4-1)} \frac{2,646}{158,942} \\
=\frac{16}{3} & 0,0166=0,0888
\end{aligned}
\end{gathered}
$$

Dengan $\alpha=0,05 ; F_{(0,05 ; 3,16)}=3,24$

Keputusan: terima $H_{o}$ karena $W<F_{(0,05 ; 3,16)}: 0,0888<3,24$ 
6. Simpulan, karena $W_{\text {Hitung }}<F_{(0,05 ; 3,16)}$ atau $0,0888<3,24$. Maka dapat disimpulkan bahwa keempat kelompok memiliki variansi yang sama.

\section{d. Uji Bartlett}

Uji Bartlett didasarkan pada suatu statistik yang distribusi teroknya memberikan nilai kritis yang tepat bila ukuran teroknya sama. Nilai-nilai kritis ini untuk ukuran terok yang sama dapat pula digunakan untuk menghasilkan hampiran nilai-nilai kritis yang amat teliti untuk ukuran terok yang tidak sama. Namun demikian, uji Bartlett sangat peka terhadap ketidaknormalan distribusi, sehingga perlu ada uji normalitas distribusi skor masing-masing kelompok. Hipotesis yang diajukan adalah:

$H_{o}: \sigma_{1}^{2}=\sigma_{2}^{2}=\cdots=\sigma_{k}^{2}$

$H_{1}$ : tidak semua variansi sama

Langkah-langkah dalam uji Bartlett adalah:

1. Tentukan variansi masing-masing kelompok yaitu $s_{1}^{2}, s_{2}^{2}, \ldots, s_{k}^{2}$

2. Tentukan variansi gabungan yaitu:

$$
s_{p}^{2}=\frac{\sum_{i=1}^{k}\left(n_{i}-1\right) s_{i}^{2}}{N-k}
$$

Dimana $\mathrm{N}$ adalah jumlahsemua terok dan $\mathrm{k}$ adalah jumlah kelompok

3. Tentukan $b$ sebagai nilai peubah acak $B$ yang berdistribusi Bartlett, yaitu:

$$
b=\frac{\left[\left(s_{1}^{2}\right)^{n_{1}-1}\left(s_{2}^{2}\right)^{n_{2}-1} \ldots\left(s_{k}^{2}\right)^{n_{k}-1}\right]^{1 /(N-k)}}{s_{p}^{2}}
$$

4. Kriteria pengujian:

a. Jika $n_{1}=n_{2}=\cdots=n_{k}=n$, maka tolak $H_{o}$ pada taraf keberartian $\alpha$ bila $b<b_{k}(\alpha, n)$

b. Jika ukuran terok tidak sama maka tolak $H_{o}$ pada taraf keberartian $\alpha$ bila:

$$
\begin{aligned}
& b<b_{k}\left(\alpha ; n_{1}, n_{2}, \ldots, n_{k}\right) \\
& b_{k}\left(\alpha ; n_{1}, n_{2}, \ldots, n_{k}\right) \cong \frac{n_{1} b_{k}\left(\alpha ; n_{1}\right)+n_{2} b_{k}\left(\alpha ; n_{2}\right)+\cdots+n_{k} b_{k}\left(\alpha ; n_{k}\right)}{N}
\end{aligned}
$$

Untuk soal pada uji Lavene dapat kita lakukan uji Bartlett

Contoh;

Tabel 3. Skor hasil uji coba 4 metode dalam suatu penelitian

\begin{tabular}{|c|c|c|c|}
\hline Kelompok A & Kelompok B & Kelompok C & Kelompok D \\
\hline 25 & 26 & 21 & 28 \\
30 & 31 & 29 & 28 \\
32 & 38 & 29 & 36 \\
36 & 39 & 31 & 37 \\
40 & 39 & 37 & 39 \\
\hline
\end{tabular}

Penyelesaian:

1. Hipotesis yang diajukan adalah:

$$
\begin{aligned}
& H_{o}: \sigma_{1}^{2}=\sigma_{2}^{2}=\sigma_{3}^{2}=\sigma_{4}^{2} \\
& H_{1}: \sigma_{1}^{2} \neq \sigma_{2}^{2}=\sigma_{3}^{2}=\sigma_{4}^{2}
\end{aligned}
$$


2. Tetapkan Tingkat signifikansi $\alpha=0,05$

3. Tetapkan Daerah Kritis, yakni daerah dimana $H_{o}$ jika $b<b_{4}(0,05 ; 5)$

Sesuai dengan langkah-langkah uji Bartlett, terlebih dahulu ditentukan masing-masing variansi kelompok, dari perhitungan pada uji Harley diperoleh:

Variansi Kelompok $A=32,8$

Variansi Kelompok $B=34,3$

Variansi Kelompok $C=32,8$

Variansi Kelompok $D=27,8$

Dari variansi di atas ditentukan variansi gabungan, yaitu:

$$
\begin{aligned}
s_{p}^{2} & =\frac{\sum_{i=1}^{k}\left(n_{i}-1\right) s_{i}^{2}}{N-k} \\
& =\frac{4.32,8+4.34,3+4.32,8+4.27,8}{20-4}
\end{aligned}
$$

Jadi $s_{p}^{2}=\frac{510,8}{16}=31,925$

Selanjutnya tentukan nilai $b$

$$
\begin{aligned}
b & =\frac{\left[\left(s_{1}^{2}\right)^{n_{1}-1}\left(s_{2}^{2}\right)^{n_{2}-1} \ldots\left(s_{k}^{2}\right)^{n_{k}-1}\right]^{1 /(N-k)}}{s_{p}^{2}} \\
& =\frac{\left[\left(s_{1}^{2}\right)^{5-1}\left(s_{2}^{2}\right)^{5-1}\left(s_{3}^{2}\right)^{5-1}\left(s_{4}^{2}\right)^{5-1}\right]^{1 /(20-4)}}{31,925} \\
& =\frac{\left[(32,8)^{4}(34,3)^{4}(32,8)^{4}(27,8)^{4}\right]^{1 / 16}}{31,925}
\end{aligned}
$$

Jadi $b=0,9969$

Setelah nilai $b$ diperoleh, bandingkan dengan nilai $b_{4}(0,05 ; 5)$. Nilai $b_{4}(0,05 ; 5)$ dilihat dari Tabel uji Bartlett. Dari Tabel diperoleh nilai $b_{4}(0,05 ; 5)=0,5850$.

Dari hasil $b$ dan $b_{4}(0,05 ; 5)$, dapat dilihat bahwa $b>b_{4}(0,05 ; 5)$, yaitu $0,9969>$ 0,5850. Sehingga diputuskan terima $H_{o}$ artinya, variansi keempat kelompok sama.

Uji homogenitas varians populasi dilakukan dengan menggunakan cara lain dari uji Bartlett. Dengan $\mathrm{H}_{0}: \sigma_{1}{ }^{2}=\sigma_{2}{ }^{2}=\ldots=\sigma_{5}{ }^{2}, \mathrm{H}_{1}$ : salah satu $\sigma^{2}$ tidak sama. Pengujiannya dilakukan dengan langkah-langkah sebagai berikut:

1. Menghitung variansi masing-masing sampel dengan rumus;

$$
S^{2}=\frac{n\left[\left(\sum f_{i} x_{i}^{2}\right)-\left(\sum f_{i} x_{i}\right)\right]^{2}}{n(n-1)}
$$

Sehingga diperoleh $s_{1}^{2}, s_{2}^{2}, s_{3}^{2}, s_{4}^{2}$, dan $s_{5}^{2}$ seperti yang tertera pada Tabel berikut : 
Tabel 4. Tabel Uji Bartlett

\begin{tabular}{|c|c|c|c|c|c|c|}
\hline Sampel & $\mathrm{n}$ & $\mathrm{dk}=\mathrm{n}-1$ & $1 / \mathrm{dk}$ & $\mathrm{S}_{\mathrm{i}}{ }^{2}$ & $\log \mathrm{S}_{\mathrm{i}}^{2}$ & $(\mathrm{dk}) \log \mathrm{S}_{\mathrm{i}}^{2}$ \\
\hline VIII A & 32 & 31 & 0,0322 & 66,22 & 1,82 & 56,42 \\
VIII B & 32 & 31 & 0,0322 & 80,06 & 1,90 & 58,9 \\
VIII C & 31 & 30 & 0,0333 & 108,84 & 2,03 & 60,9 \\
VIII D & 34 & 33 & 0,0303 & 99,86 & 1,99 & 65,67 \\
VIII E & 33 & 32 & 0,0312 & 92,25 & 1,96 & 62,72 \\
$\sum$ & 162 & 157 & 0.1592 & 447,23 & 9,7 & 304.61 \\
\hline
\end{tabular}

2. Menghitung varians gabungan dari semua kelompok sampel dengan rumus:

$S^{2}=\frac{\sum\left(n_{i}-1\right) S_{i}^{2}}{\sum\left(n_{i}-1\right)}$

Sehingga diperoleh varians gabungan sebagai berikut:

$$
S^{2}=\left(\frac{31.66,22+\cdots+32.92,25}{31+31+30+33+32}\right)
$$

$$
S^{2}=92,198
$$

3. Menghitung harga satuan Bartlett dengan rumus berikut dan hasil yang diperoleh sebagai berikut:

$$
\begin{aligned}
& B=\left(\log S^{2}\right) \sum\left(n_{i-} 1\right) \\
& =(\log 92,198)(157) \\
& \text { Jadi } \mathrm{B}=308,348
\end{aligned}
$$

4. Menghitung harga Chi-Kuadrat $\chi^{2}$

$$
\begin{aligned}
\chi^{2} & =\ln 10\left\{B-\sum\left(n_{i}-1\right) \log S_{i}^{2}\right\} \text { dengan } \ln 10=2,303 \\
& =2,303(308,348-304,61)
\end{aligned}
$$

Jadi $X^{2}=8,609$

5. Gunakan tabel $\chi^{2}$ untuk $\alpha=0,05$

$$
\begin{aligned}
\chi_{\text {tabel }}^{2} & =\chi_{(1-\alpha ; k-1)}^{2} \\
& =\chi_{(0,95 ; 4)}^{2} \\
\text { Jadi } X^{2} & =9,488
\end{aligned}
$$

Dari perhitungan di atas diperoleh $\chi_{\text {hitung }}^{2}<\chi_{\text {tabel }}^{2}$ dimana $\mathbf{8 , 6 0 9}<\mathbf{9 , 4 8 8}$. Sehingga dapat disimpulkan bahwa $\mathrm{H}_{0}:{\sigma_{1}}^{2}=\sigma_{2}{ }^{2}=\ldots=\sigma_{5}{ }^{2}$ diterima atau tidak ada perbedaan varians antara sampel-sampel yang diambil pada $\alpha=0,05$.

\section{B. Uji Normalitas}

Uji normalitas yang paling sederhana adalah membuat grafik distribusi frekuensi atas skor yang ada. Pengujian kenormalan tergantung pada kemampuan kita dalam mencermati plotting data. Jika jumlah data cukup banyak dan penyebarannya tidak 100\% normal ( tidak normal sempurna), maka kesimpulan yang ditarik kemungkinan akan salah. Pada saat sekarang ini sudah banyak cara yang dikembangkan para ahli untuk melakukan pengujian normalitas. Beberapa diantaranya adalah Uji Kolmogorov-Smirnov dan Uji Lilliefors. 


\section{Uji Kolmogorov Smirnov}

Dalam uji Kolmogorov Smirnov hipotesis yang diajukan adalah:

$\mathrm{H}_{\mathrm{o}}: \mathrm{f}(\mathrm{X})=$ normal

$\mathrm{H}_{1}: \mathrm{f}(\mathrm{X}) \neq$ normal

Langkah-langkah dari uji Kolmogorov Smirnov adalah:

a. Menentukan rata-rata dan standar deviasi data

b. Menyusun data dimulai dari yang terkecil diikuti dengan frekuensi masing-masing, frekuensi kumulatif (F) dari masing-masing skor. Nilai $\mathrm{Z}$ ditentukan dengan rumus;

Z skor $=\frac{X-\bar{X}}{\sigma}$

Dimana:

$\bar{X}=$ rata - rata

$\sigma=$ simpangan baku

$\sigma=\sqrt{\frac{\sum\left(x_{i}-\bar{x}\right)^{2}}{n-1}}$

c. Tentukan Probabilitas dibawah nilai $Z$ yang dapat dilihat pada table $Z(P \leq Z)$

d. Tentukan nilai selisih masing- masing baris $F / n=F z$ dengan $P \leq Z$ (nilai $a_{2}$ ) dan selisih masing-masing $f / n$ dengan $a_{2}$ (nilai $a_{1}$ )

e. Selanjutnya bandingkan nilai tertinggi dari $a_{1}$ dengan Tabel Kolmogorov Smirnov.

f. Selanjutnya Kriteria Pengujian adalah:

Terima $H_{o}$ jika $a_{1}$ maks $\leq D_{\text {tabel }}$

Tolak $H_{o}$ jika $a_{1}$ maks $>D_{\text {tabel }}$

\section{Contoh:}

Dari sebuah penelitian tentang Model Pembelajaran ARCSI dengan Pendekatan Saintifik diperoleh data sebagai berikut:

$\begin{array}{llllllllllll}70 & 23 & 69 & 68 & 27 & 33 & 62 & 40 & 48 & 59 & 48 & 57\end{array}$

\section{Penyelesaian:}

1. Rumusan hipotesis statistik

$$
\begin{aligned}
& H_{o}: f(X)=\text { normal } \\
& H_{1}: f(X) \neq \text { normal }
\end{aligned}
$$

2. Tetapkan tingkat signifikansi $\alpha=0,05$.

3. Tetapkan uji statistik yang digunakan, yakni: uji Kolmogorov Smirnov.

4. Tetapkan daerah kritis, yakni Nilai $a_{1}$ maks $>D_{(0,05 ; 12)}=0,375$

5. Lakukan perhitungan, yakni seperti Tabel 5 berikut ini. 
Tabel 5. Hasil perhitungan-perhitungan uji normalitas dengan Kolmogorv Smirnov

\begin{tabular}{c|c|c|c|c|c|c|c|c|}
\hline $\boldsymbol{X}$ & $\boldsymbol{f}$ & $\boldsymbol{F}$ & $\boldsymbol{f} / \boldsymbol{n}$ & $\boldsymbol{F} / \boldsymbol{n}=\boldsymbol{F} \mathbf{z}$ & $\boldsymbol{Z}$ & $\boldsymbol{P} \leq \boldsymbol{Z}$ & $\boldsymbol{a}_{\mathbf{1}}$ & $\boldsymbol{a}_{\mathbf{2}}$ \\
\hline 23 & 1 & 1 & 0,0833 & 0,0833 & $-1,588$ & 0,057 & 0,057 & 0,026 \\
27 & 1 & 2 & 0,0833 & 0,1667 & $-1,358$ & 0,088 & 0,005 & 0,078 \\
33 & 1 & 3 & 0,0833 & 0,2500 & $-1,011$ & 0,156 & $-0,010$ & 0,094 \\
40 & 1 & 4 & 0,0833 & 0,3333 & $-0,608$ & 0,271 & 0,021 & 0,062 \\
48 & 2 & 6 & 0,1667 & 0,5000 & $-0,147$ & 0,440 & 0,107 & 0,059 \\
57 & 1 & 7 & 0,0833 & 0,5833 & 0,372 & 0,644 & $\mathbf{0 , 1 4 4} *$ & $-0,061$ \\
59 & 1 & 8 & 0,0833 & 0,6667 & 0,487 & 0,688 & 0,104 & $-0,021$ \\
62 & 1 & 9 & 0,0833 & 0,7500 & 0,661 & 0,745 & 0,079 & 0,004 \\
68 & 1 & 10 & 0,0833 & 0,8333 & 1,006 & 0,844 & 0,094 & $-0,010$ \\
69 & 1 & 11 & 0,0833 & 0,9166 & 1,064 & 0,855 & 0,022 & 0,061 \\
70 & 1 & 12 & 0,0833 & 1 & 1,122 & 0,868 & $-0,048$ & 0,131 \\
\hline
\end{tabular}

Dari tabel perhitungan uji kolmogorov smirnov di atas, diperoleh nilai tertinggi dari $a_{1}=0,144$. Bandingkan dengan nilai tabel Kolmogorov Smirnov yaitu $D_{(0,05 ; n)}=$ $D_{(0,05 ; 12)}=0,375$.

6. Simpulan, apabila dibandingkan nilai maksimal $a_{1}$ dengan nilai $D$ terlihat bahwa nilai maks $a_{1} \leq D_{(0,05 ; 12)}$, artinya terima $H_{o}$ sehingga disimpulkan bahwa data berdistribusi normal.

\section{b. Uji Lilliefors}

Uji normaliatas dengan uji Lilliefors merupakan uji kenormalan secara non parametrik. Uji Lilliefors juga merupakan penyempurnaan dari rumus Kolmogrov-Smirnov sehingga sifatnya menyederhanakan.

Rumusan Hipotesis untuk uji Lilliefors ini adalah:

$H_{o}: f(X)=$ normal

$H_{1}: f(X) \neq$ normal

Untuk pengujian hipotesis tersebut dilakukan langkah-langkah yang hampir sama dengan langkah pada uji Kolmogorov-Smirnov, yaitu:

a. Menentukan rata-rata dan standar deviasi data

b. Menyusun data dimulai dari yang terkecil diikuti dengan frekuensi masing-masing, frekuensi kumulatif $(F)$ dari masing-masing skor. Nilai $Z$ ditentukan dengan rumus;

Z skor $=\frac{X-\bar{X}}{\sigma}$

Dimana:

$\bar{X}:$ rata - rata

$\sigma:$ simpangan baku

$\sigma=\sqrt{\frac{\sum\left(x_{i}-\bar{x}\right)^{2}}{n-1}}$

c. Tentukan Probabilitas dibawah nilai $Z$ yang dapat dilihat pada table $Z(P \leq Z)$

d. Tentukan nilai selisih masing-masing baris $F / n=F z$ dengan $P \leq Z$ dan tentukan harga mutlaknya. 
e. Ambil harga yang paling maksimum dari harga-harga mutlak tersebut, sebut harga terbesar itu dengan $L_{o}$

f. Selanjutnya bandingkan nilai $L_{o}$ dengan table uji Lilliefors.

g. Selanjutnya Kriteria Pengujian adalah:

Tolak $H_{o}$ jika $L_{o}>L_{\text {tabel }}$

Terima $H_{o}$ jika $L_{o} \leq L_{\text {tabel }}$

Contoh: Soal pada uji Kolmogorov-Smirnov, dapat digunakan untuk uji Lilliefors.

Dari sebuah penelitian tentang Model Pembelajaran ARCSI dengan Pendekatan Saintifik diperoleh data sebagai berikut:

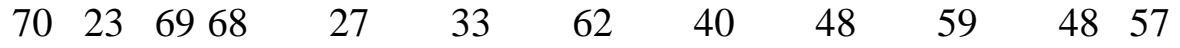

\section{Penyelesaian:}

Tabel 6. Hasil perhitungan-perhitungan uji normalitas dengan Lilliefors

\begin{tabular}{ccc|c|c|c|c|c|c|}
\hline $\boldsymbol{X}$ & $\boldsymbol{f}$ & $\boldsymbol{F}$ & $\boldsymbol{f} / \boldsymbol{n}$ & $\boldsymbol{F} / \boldsymbol{n}=\boldsymbol{S}\left(\mathbf{z}_{\boldsymbol{i}}\right)$ & $\boldsymbol{Z}$ & $\boldsymbol{P} \leq \boldsymbol{Z}=\boldsymbol{F}\left(\mathbf{z}_{\boldsymbol{i}}\right)$ & $\left|\boldsymbol{F}\left(\mathbf{z}_{\boldsymbol{i}}\right)-\boldsymbol{S}\left(\mathbf{z}_{\boldsymbol{i}}\right)\right|$ \\
\hline 23 & 1 & 1 & 0,0833 & 0,0833 & $-1,588$ & 0,057 & 0,0262 \\
27 & 1 & 2 & 0,0833 & 0,1667 & $-1,358$ & 0,088 & 0,0782 \\
33 & 1 & 3 & 0,0833 & 0,2500 & $-1,011$ & 0,156 & 0,0938 \\
40 & 1 & 4 & 0,0833 & 0,3333 & $-0,608$ & 0,271 & 0,0624 \\
48 & 2 & 6 & 0,1667 & 0,5000 & $-0,147$ & 0,440 & 0,0596 \\
57 & 1 & 7 & 0,0833 & 0,5833 & 0,372 & 0,644 & 0,0609 \\
59 & 1 & 8 & 0,0833 & 0,6667 & 0,487 & 0,688 & 0,0212 \\
62 & 1 & 9 & 0,0833 & 0,7500 & 0,661 & 0,745 & 0,0046 \\
68 & 1 & 10 & 0,0833 & 0,8333 & 1,006 & 0,844 & 0,0104 \\
69 & 1 & 11 & 0,0833 & 0,9166 & 1,064 & 0,855 & 0,0613 \\
70 & 1 & 12 & 0,0833 & 1 & 1,122 & 0,868 & $\mathbf{0 , 1 3 1 4}$ \\
\hline
\end{tabular}

Dari tabel perhitungan uji Lilliefors di atas, diperoleh nilai tertinggi dari harga mutlak $\left|\boldsymbol{F}\left(\mathbf{z}_{\boldsymbol{i}}\right)-\boldsymbol{S}\left(\mathbf{z}_{\boldsymbol{i}}\right)\right|=L_{o}=0,1314$. Bandingkan dengan nilai Tabel uji Lilliefors yaitu $L_{(0,05 ; n)}=L_{(0,05 ; 12)}=0,242$. Apabila dibandingkan nilai maksimal $L_{o}$ dengan nilai $L$ terlihat bahwa $L_{o}=0,1314<0,242=L_{(0,05 ; 12)}$, artinya terima $H_{o}$ sehingga disimpulkan bahwa data berdistribusi normal.

\section{KESIMPULAN DAN SARAN}

Berdasarkan pembahasan dapat disimpulkan bahwa uji persyaratan analisis sangat dibutuhkan, dalam rangka seorang peneliti menguji hipotesis statistik yang diajukan. Uji persyaratan analisis berupa uji homogenitas dan uji linearitas. Uji homogenitas varians populasi dapat dilakukan dengan beberapa statistik uji, yakni: uji Harley, uji Cohran, Uji Levene, dan uji Bartlett. Sedangkan uji normalitas dapat dilakukan dengan Uji Kolmogorov-Smirnov dan Uji Lilliefors.

Langkah-langkah dari uji hipotesis statistik, yakni: (1) rumuskan hipotesis $\mathrm{H}_{0}$ dan $\mathrm{H}_{1}$; (2) Tetapkan tingkat signifikansi $\alpha$; (3) Tetapkan daerah kritis atau daerah dimana $\mathrm{H}_{0}$ ditolak atau $\mathrm{H}_{1}$ diterima; (4) Tetapkan statistik uji; (5) Lakukan perhitungan; (6) Ambil kesimpulan. 
Berdasarkan pembahasan dan simpulan di atas, betapa pentingnya uji prasyarat analisis ini, maka penulis menyarankan kepada para peneliti agar memperhatikan uji prasyarat analisis terlebih dahulu sebelum melakukan uji hipotesis, agar pengujian hipotesis yang telah kita ajukan, sesuai dengan uji statitika inferensial yang kita butuhkan dalam mengolah data hasil penelitian.

\section{DAFTAR PUSTAKA}

Agus Irianto. Statistik. Konsep Dasar;Aplikasi, dan Pengembangan. Jakarta: Kencana

Ergusni. 2015. Uji Hipotesis AnalisisBeda Rerata Dua Sampel (Uji-t dan t'). Prosiding Seminar Nasional matematika dan Pendidikan Matematika. STKIP PGRI Padang.

Sudjana. 1996. Metode Statistik. Tarsito. Bandung.

Sugiyono. 2004. Statistik NonParametrik untuk Penelitian. Alfabeta, Bandung.

Supardi U.S. 2013. Aplikasi Statitika Dalam Penelitian (Konsep Statitika yang Lebih Komprehensif). Change Publication. Jakarta. Indonesia.

Usmadi. 2015. Uji Tukey dan Uji Schefee Uji Lanjut (Post Hoc Test). Prosiding Seminar Nasional matematika dan Pendidikan Matematika. STKIP PGRI Padang.

Walpole, R. dan Myers, R. 1995. Ilmu Peluang dan Statistik untuk Insinyur dan Ilmuwan. Bandung. ITB. 